\title{
Turkey and the Gulf States: Threats and Prospects
}

\author{
Yusuf Ibrahim Gamawa
}

\begin{abstract}
Until recently, the republic of Turkey does not get involved in the affairs of the Gulf states or the Middle East as whole, except during the years of the Ottoman Empire when the whole of the Middle East came under Ottoman Turkey. However since the founding the new republic by Kemal Ataturk and its westernization policy, Turkey had all the time looked to the west and only in the 2000's began to be involved in the affairs and politics of the gulf region. The Gulf region remains strategic to many outside powers like the U.S, Russia and the E.U states as a result of it energy resources. Within the region there has been fierce rivalry for power and domination among the Gulf States. The rivalry and struggle for influence is seen to be particularly between Saudi Arabia and Iran. The Gulf States view Iran with suspicion for its ambition in the region and feel threatened by Iran's nuclear development program. The Gulf States therefore welcomed the entrance of Turkey into the affairs of the region mainly with the hope that it could counter Iranian influence in the region. The paper argues that the republic of Turkey must strike a balance between its interest in the region and the interests of its Gulf partners and its relations with Iran on the one hand. The necessity of policy choice and balance by the republic of Turkey is based on the Realist classical theory of International Relations.
\end{abstract}

Keywords: Turkey, Gulf, Iran, perceptions, policy.

\section{INTRODUCTION}

Since the $16^{\text {th }}$ Century, until 1920 the entire region that is today known as the Gulf region or the Middle East had been under Ottoman control. The British during the World War I moved against the Ottomans, and this saw the transformation of Arab nationalism into a campaign against their Turkish masters. And after the War, the French and the British were seen to have come up with a new map for the region as mandatory powers. The region had come under the domination and control of various rulers since the French and the British relinquished their control of the region and granted independence to the emerging nation States. After the fall of the Ottoman's from influence in the entire Middle East, the balance of power in the Middle East came to be shaped by Iran. Turkey was seen to have become involved in the affairs of the region and of the Gulf States only recently, and its main interest in the Gulf States of Saudi Arabia, Kuwait, Bahrain, Oman, U.A.E, and Qatar, is mainly trade and energy resources, whereas its interest in the entire region appears to be mainly security. And since Turkey's involvement with the Gulf States, it has stirred up expectation about its perceived role in the wider region by its Gulf partners, who seem to be interested in creating a role for Turkey in the Middle Eastern region as a whole. Turkey on its part appears to have articulated its policies towards the region since it came up with its new foreign policy of zero problems with neighbors based on which it reached out to the Gulf States. There appears to be a kind of conflict of interest between Turkey and the Gulf States regarding Turkey's role in the region, and the expectations of the Gulf partners.

However, in the mean time, Turkey's interests are restricted to trade and energy resources, and Turkey does not appear to be willing to play a regional role, though in recent times it 
became involved in the Syrian conflict. As a result, this article insists that Turkey must be able to balance its role with the Gulf States, and its role in the wider Middle East region. And here Turkey will be faced with the problem of a policy choice, that would not appear to complicate its relations with the Gulf States, and with the Middle Eastern countries, or bring it into confrontation with countries such as Iran, who are seen to have enormous influence in the region, and a country that many of the Gulf States feel threatened by, especially as a result of its nuclear program.

The article generally takes a look at the relations between Turkey and the Six Gulf States, whose brief overview is presented in the article, beginning with a background from the Ataturk era, and a discuss on the relations with the Gulf states and trade relations as well, which is followed by Turkey's relations with Iran, Syria, Palestine and Israel, a relations which is seen to be closely related or sometimes defines its relations with the states in the Gulf. It is then followed by Turkey's role in the Gulf, which tries to explain the two perspectives of the anticipated role of the republic Turkey. This is followed by a brief on the perceptions of the Gulf States, and that of Turkey concerning the involvement of Turkey in the region; it shows the expectations and the realities of the relations between the two. The implications of policy choice for Turkey, was considered to make the last part of the paper which is followed by a conclusion of the entire article.

\section{BACKGROUND}

The founding of the Turkish republic in 1923 marked the end of the Ottoman Empire which had enjoyed considerable influence and total control, not just within Turkey, but in Middle East, parts of Asia, Africa and Europe. The Empire brought the entire Middle East region under its control, and the Turks remained the custodians of the three holy places of Mecca, Medina and Jerusalem. But with the demise of the empire and the emergence of nation states in the Middle East region, Turkey had to redefine its relation with the region. The leadership of Turkey under Kemal Ataturk was significant in determining the policy direction of the new republic towards the Middle East. At the founding of the republic, the policy of Kemal Ataturk was generally seen to be as one of consolidating the republic ${ }^{1}$. In a speech in October 1927, Ataturk was quoted as emphasizing the insignificance of seeking an empire beyond Turkish lands. The speech by Ataturk reminded Turkish people of their misfortunes in the lands of the Middle East, where the Turks lost soldiers to conflicts, which featured in many folklore Turkish songs. And likewise the Arabs continued to remember and highlight their sufferings, in what they described as a repressive and oppressive rule under the many years of Ottoman control over Arabia, until their revolt and subsequent independence ${ }^{2}$. The Arabs tried as much as possible to keep away from Ottoman Turkey, and avoided anything that would link it to a subservient status of the past, which they considered with much degradation. The Arabs continue to describe the victorious manner in which they liberated themselves from Ottoman control.

The period of Ataturk's rule witnessed an era of transformation from within Turkish society that was to see Turkey moving towards westernization. The new republic tended to become more and more engaged in Europe than anywhere else, not even the Middle East. This remained the policy direction of the republic between 1923 and 1938 when Kemal Ataturk died. However, it is significant to note that his ideology and philosophy had become rooted in Turkish society, particularly among the ruling elites, who vowed to continue to pursue his

\footnotetext{
${ }^{1}$ Sean Foley, "Turkey and the Gulf States in the Twenty-First Century", September 3, 2010,p 1

${ }^{2}$ Ibid.p 1
} 
policies and ideas, especially his westernization policy of Turkey ${ }^{3}$. Ever since then, Turkey remained tied to the West, and joined NATO during the Cold War period, which is a Western Military alliance spearheaded by the United States.

\section{An Overview of the Gulf States}

Arabia, the area made up of the Arabian Peninsula is located in the southwestern region of the Asian Continent. It covers an area of about 3 million sq km; the southeastern area of the Peninsula is the Rub-al-Khali, the Empty Quarter, which is the world's largest expanse of continuous sand. The Arabian Peninsula consists of Saudi Arabia, Kuwait, Bahrain, Qatar, The U.A.E and the Sultanate of Oman.

\section{Saudi Arabia}

Saudi Arabia is the dominant power in the Arabian Peninsula culturally, geographically, demographically and economically. It has a population of 25.534.504 Million in 2012 and operates a Monarchical system of government. Islam's two holy cities of Mecca and Medina are located in the country, thereby giving it a unique influence and importance all over the Muslim World. Saudi Arabia exports 7.635 Million bbl/day and has a proven oil reserve of almost 265 Billion Barrels, about $20 \%$ of the World's total proven reserve ${ }^{4}$.

\section{Kuwait}

The country's geography renders it susceptible to external influence, it shares a long border with Iraq, and the Kuwait city itself is $50 \mathrm{KM}$ away from Iran. Unlike most Gulf States, Kuwait has always considered Iraq as its biggest threat as a result of the Iraq invasion in 1990. Though there is a change in such perception in recent times. Kuwait takes a more restrained approach to regional affairs and tends to align its foreign policy with that of Saudi Arabia ${ }^{5}$. It operates a constitutional Emirate system of government, and has a population of 2.646 .314 in 2012. It exports 2.127 Million bbl/day and has an oil reserve of 104 billion bbl.

\section{Bahrain}

The country operates a constitutional monarchy system of government, and has a population of 1.248.348 Million in 2012. The thirteen years rule of King Hamad Bin Isa Al-Khalifa undertook reforms that were seen to have transformed the Kingdom into a banking hub that has been attracting foreign companies, Gulf tourists and the Formula One Grand Prix competition. The country exports $239.900 \mathrm{bbl}$ of oil per day and has a reserve of 124.6 Million bbl.

\section{Qatar}

Qatar is the world's wealthiest state on a per-capita basis, with only 1.951.591 Million citizens and the third largest natural gas reserves. The country succeeded in transforming the extraordinary wealth into outsized regional and global influence. Qatar shares with Iran the North/South Pas reservoir, the largest gas field in the world ${ }^{6}$. Qatar exports 1.038 Million bbl of oil per day and a reserve of 25.38 Billion bbl.

\footnotetext{
3 Ibid p 1

4 "The Gulf Security Architecture: Partnership with the Gulf Cooperation Council”, A Majority Staff Report Prepared for the Use of the Committee on Foreign Relations United States Senate, One Hundred Twelfth Congress, Second Session, June 19, 2012.p 9

5 Ibid.p 11

${ }^{6}$ Ibid.p 13
} 


\section{The U.A.E.}

The U.A.E is a unique federal state comprised of seven emirates ruled by hereditary royal families. It was known as the Trucial State before the U.A.E became fully independent in 1971. It has a population of 5.314.317 Million in 2012, an oil export of 2.395 Million bbl per day and a reserve of 97.8 Billion bbl. The federation emerged through series of treatise signed between individual Sheikhdoms and the United Kingdom during the 150 year British protectorate period. Abu Dhabi, the capital is the country's centre of political, economic and cultural gravity. Dubai is an open, cosmopolitan city that has emerged in recent decades as a global business and tourism hub ${ }^{7}$.

\section{Oman}

The country has a rich history and a strategic location whose territorial waters contain the major navigable shipping lanes of the Strait of Hormuz. It has a population that is neither predominantly Sunni nor Shiite which totals 3.090.150 Million in 2012. The Sultanate of Oman has carved out a unique position within the $\mathrm{GCC}^{8}$. The country has a daily oil export of 592.300 bbl and a reserve of 5.5 Billion bbl.

\section{Gulf States and Relations with Turkey}

The relations between Turkey and the Arab world has dramatically changed over the years, and the country's relations with the Middle East was seen to have taken a new turn, particularly with many of the GCC States of Saudi Arabia, U.A.E, Kuwait, Bahrain, Qatar and Oman. Several reasons have been advanced for the emergence of these new relations. The dramatic shift in Turkey's foreign policy principles was seen to have been amongst other factors that led to such development. ${ }^{9}$ Other significant factors that were seen to have aided the relations between Turkey and the Gulf States include the realization on the part both the Gulf States and Turkey that a mutual alliance could reduce their dependence on the EU for Turkey, and the U.S. for the Gulf States. The instability and collapse of the oil market in the 1990's and after the Iraqi invasion, was also seen to have transformed the perception of the Gulf States. The coming to power of the AK Party, with new officials that promoted a new policy of engaging the neighborhood cannot be underestimated or ignored. Turkey's new foreign Minister, Ahmet Davotoglu's new vision and foreign policy principles of "zero problem with neighbors" was seen to have been specifically articulated to reconcile Turkey's relations with her Middle Eastern neighbors ${ }^{10}$. The policy itself was seen to have come about as a result of certain disputes bedeviling its relations with the Gulf countries, which include economic reasons also. The policy was also seen to have aimed at creating a stable environment for economic prosperity. Basically, the Kurdish insurgency across the Iraqi border was of great concern for Turkey. At the same time, economically, the Gulf region appeared to be a vast market for Turkish exports, as well as the need for Turkey to increase its exports due to the economic recession of the time, which the Turkish economy faced. These among other reasons forced the Turks to renew their ties with the Gulf countries, as it became much clearer that the European market alone could not sustain the ever growing Turkish economy.

The new foreign policy was seen to have made a significant impact on the economy of Turkey, and between 2002 and .2007, the per capita income had doubled and the economic growth

\footnotetext{
7 Ibid.p 15

8 Ibid.p16

9 Ibid.p 4

${ }^{10}$ Sean Foley, "Turkey and the Gulf States in the Twenty-First Century", September 3, 2010,p 3.
} 
remained at about $7 \%$ on average ${ }^{11}$. Turkey's relations with the Gulf countries was seen to have particularly improved after Turkey declined a request from the U.S to use its land for the invasion of Iraq in $2003^{12}$, even though Turkey agreed to the request, the U.S. at this time declined to accept Turkey's participation in the operation. But the fact that Turkey from the beginning refused to the request, gladdened many of the Gulf States who were against the invasion. This helped change the perception of the Gulf countries about Turkey, which was considered as blindly supporting Western interest in the region. The Iraqi stance of Turkey marked a watershed in the history of Turkey's relations with the Gulf States. Turkey's involvement in the OIC was also seen to have deepened cooperation with the Gulf States at a time when Turkey was re-aligning it policies to suit its relations with the Gulf States, Ekmelledin Ihsanoglu, a Turk emerged as the Secretary General of the OIC ${ }^{13}$. This was followed by Turkey's attainment of an observer status in the Arab league, and the Gulf States were seen to have given Turkey their support for a seat in the UN Security Council. As a result of the good relations, the Gulf State's foreign Ministers signed a memorandum of understanding with the republic in the area of commerce and trade in Saudi Arabia. The Gulf States were also seen to have supported both U.S. and NATO policies of the Middle East Initiative, as well as security relations with the GCC States, with Turkey assuming a new role of a mediator in the Arab/Israeli conflict and the Kurdish problem by supporting a unified Iraq.

\section{Trade and Economic Relations}

Trade and commerce remained the most important aspect of the relationship of the Gulf States and Turkey. Gulf corporations and individuals from Kuwait, Dubai and Saudi Arabia were seen to have made investments in real estate, Banks, Hospitals and Educational institutions in Turkey that ran into Billions of dollars. Most of them acquired shares in Turkish companies like Turk cell, Turkey's largest Mobile telecommunications company, which negotiated with a Saudi firm, Oger a 55\% stake at a cost of about 6.5 Billion USD. Gulf countries investment in Turkey grew from nothing in 2003, to 2 Billion dollars in 2008. Whereas Gulf-Turkey trade was seen to have grown from 17 Billion dollars in 1998 to 166 Billion dollars in 2008.This difference can be seen in the fact that between 2001 and 2003 total exports to Saudi Arabia from Turkey only rose from 729, 644 Dollars to 738, 004 Dollars, to Bahrain it reduced from 11,159 Dollars to 28, 62 Dollars. To UAE, it reduced from 380,145 Dollars to 697,71 Dollars, and to Qatar it fell from 8,401 Dollars to 15, 68 Dollars, and to Kuwait it fell from 104,769 Dollars to 164,88 Dollar, while to Oman it fell from 31,449 Dollars to only 22,31 Dollars ${ }^{14}$. So the massive improvement in trade can be seen between 2003 and 2008. Turkish companies were seen to have won contracts that ran into Billions of dollars in the Gulf countries. In Qatar Turkish companies were awarded three separate contracts of building a museum at 124 Million dollars, construction of a library at 245 Million dollars, and an 869 Million dollars contract of building a new terminal at the Doha International airport, as well as managing the airport, among other contracts in the region by Turkish companies. UAE firm, Dubai international properties, a leading developer signed an agreement with the Municipality of Istanbul to build a business centre that is valued at 5 Billion Dollars. Apart from this, a Dubai Islamic bank bought Turkish owned MNG Bank for 160 Million Dollars, with ten branches in Turkey, and began operations since 199715. Kuwaiti firms were also said to have invested heavily in Turkey. In December

\footnotetext{
11 Ibid.p 4

12 Ibid.p 2

13 Ibid.p 4

${ }^{14}$ Bulent Aras, "Turkey and the GCC: An Emerging Relationship", Middle East Policy Council, 2005.p 95

15 Robert Olson, "Turkey's Relations with the Gulf Cooperation Council from 2003 to 2007: New Paragigms?", Mediterranean Quaterly, 19:3, Mediterranean Affairs, 2008.p 71
} 
2007, Kuwait's Global Investment House paid 120 Million Dollars for a 60\% share of a Turkish financial lending Firm under the name Yildiz Holding ${ }^{16}$.

\section{Turkey and Iran}

A change from within Turkish society has led to a lot of consideration to issues that were in the past seen as highly security issues. The deepening of democratic culture in Turkey is largely seen as being responsible for the emergence of this new outlook. Many have tried to link this change to EU membership process of Turkey, which has made it necessary to consider and discuss so many issues in the open, which were hitherto considered issues of national security. Issues related to human rights abuse and the Kurdish problems were in the past considered with much sensitivity and secrecy, and remained tied to national security ${ }^{17}$. The new trend of openness and liberalism is seen to have played a significant role in bringing about a change in the foreign policy of Turkey towards certain countries in the Persian Gulf region, including Iran and Syria. Security concerns regarding the Kurdish population which are present in all three countries of Turkey, Iran and Syria, and Turkey's efforts at reducing its dependence on the United States for its security since the Cyprus issue, did actually contribute in promoting Turkey's regional relations with these countries. And Turkey hoped for a long term mutual relations that will be of much benefit with Iran and Syria.

Turkey and Iran relations could best be explained in terms of the de-securitization and securitization of domestic issues in Turkey. Securitization of internal issues helped create enemy images, and helped form Turkey's security policy towards Iran in particular. The elites in Turkey had always believed that Iran was pursuing an agenda of exporting its Islamic revolution to Turkey through any means possible, and particularly by supporting Islamist groups within Turkey. Certain incidences helped create these suspicions by Turkey about Iran's motives ${ }^{18}$. One of such incidences were comments made openly by an Iranian Ambassador to Ankara, which led to what came to be known as the Bager crisis. The Ambassador, Muhammad Reza was quoted as advocating for an Islamic system of government at an Islamic rally in Turkey. The republic of Turkey has always been concerned with Issues of identity, and the secular nature of its constitution and its westernization policy, which some western nations view with suspicion. And in this way, Iran began to be perceived as a threat to the secular ideology in Turkey. Secondly, the elites in Turkey continued to claim that the Iranian regime is supporting the PKK. Though the claims may not have been completely untrue, it was seen as an uncommon behavior for nation states to blame other states for their issues. These two issues remained the fundamental problems that hindered relations between Turkey and Iran over the years, despite any other problem that may exist. Many internal issues were made to appear as arising from Iranian conspiracies to bring about instability in Turkey, particular in connection with Islamism and Kurdish activities. Turkish elites were seen to have exaggerated the dangers posed by enemy countries such as Iran, thereby holding Turkey's foreign policy hostage to such thoughts.

The articulation of a new foreign policy saw the disappearance of the stereotype attitude towards Iran, of accusations of sabotage at every opportunity as claimed by the elites for many years. The new foreign policy seemed to focus on creating a mediating role for Turkey in the region, and is seen to be based on a vision of reducing Turkey's problems with countries of the

\footnotetext{
16 Ibid.p 72

17 Bulent Aras \& Rabia Karakaya Polat, "From Conflict to Cooperation: Turkey's Relations with Syria and Iran", Sage Publications, Vol 35, No 5, 2008.p 505

18 Ibid.p 505
} 
region, with a view to avoiding any confrontation that may arise as a result of the poor relations. The policy is aimed at balancing Turkey's interest in these countries in line with the demands of the international community. Other factors that were seen to have ensured the rapid development of these relations include the investments made in Iran by Turkish companies in the oil and gas sector. Turkey continued to show an accommodating attitude, which is similar to the stance of EU countries regarding certain issues on Iran. And in this manner Turkey began to play a new role between Iran and the United Nations, concerning Iran's nuclear ambitions, under what came to be known as $5+1$, consisting of the five members of the UN Security Council and Germany. Turkey tried to prevail on Iran to adopt a more moderate attitude towards the International Atomic Energy Agency (IAEA) concerning its talks on the nuclear program. Turkey's role in the nuclear issue was also aimed at desecuritization and elimination of security threats domestically. And as a result of such involvement in the affairs of Iran, Turkey no longer considered Iran as an external threat, and the perceived Iranian threat was seen to have disappeared. The policy seemed to have boosted the confidence of Turkey to become more involved in regional and international security issues. Turkey tried to ensure that Iran keeps its nuclear program only for peaceful energy, fearing the emergence of Iraq like situation in the region ${ }^{19}$. And since then trade between Iran and Turkey continued to be on the increase, and rose from 1.2 Billion dollars to 6 Billion dollars annually. The two countries agreed to work on many projects both within and outside their countries. The relation with Iran seems to have taken care of what Erikson called the "panic mode" of securitized politics.

\section{Relations with Syria}

Like the relations with Iran, Turkey's relations with Syria suffered a similar fate, characterized mainly by distrust and mutual suspicion. And it is seen that the same policy line was adopted by Turkey in dealing with the problems it had with both Iran and Syria. The two countries had constituted a threat to domestic stability in Turkey. And for many years Turkey and Syria remained in what many called "historical enmity", due mainly to difference of ideology and effort of policy makers to externalize many domestic issues in Turkey. There were basically two major problems between Turkey and Syria, water has been a source of dispute between the two countries. Following a protocol signed in 1987, Turkey agreed to a water flow of 500 cubic meters per second to Syria, The second problem had to do with the activities of PKK and the claims in Turkey that Syria shelters the organization, which has fought the Turkish establishment for close to two decades ${ }^{20}$. The worsening of the problem had at a point made Turkey contemplate a military operation in Syria, with the aim of capturing PKK leader Abdullah Ocalan and his lieutenants. It was a situation that saw the involvement of other Gulf countries in the issue with the aim peaceful resolution of the issues between Turkey and Syria. The diplomatic move by countries such as Jordan was highly successful, it led the Syrian leader to accept the demands of Turkey, and it was followed by the signing of the Adana Accord in 1998, following which the Syrian government expelled the PKK leader, Abdullah Ocalan, in accordance with the Accord. As a result of this development Turkey was said to have increased the water flow to Syria from 500 cubic meters per second to 900 cubic meters. In 2004, when the Turkish Prime Minister visited Syria, he was quoted as saying that Syria could make use of the Tigris waters as much as it wants. The visit of the Prime Minister came after the Syrian leaders visit to Ankara in January 2004, where Assad was quoted as saying "we have together

19 Ibid.p 508

20 Ibid.p 509 
shifted from an atmosphere of distrust to trust"21. And ever since then the relations between Turkey and Syria changed to that of friendship and cooperation, in line with Turkey's new foreign policy, until the recent Arab spring and the Syrian unrest. Turkey felt the need to involve Syria in many regional issues, which include the future of Iraq, as well as the Israeli/Palestinian conflict. An agreement was signed between the two countries on free trade, and was further expanded to include cooperation and interdependence.

\section{Turkey, the Palestinian Question and Relations with Israel}

Since the creation of the State of Israel in 1948, after the withdrawal of the British as Mandatory authorities, there has been series of Wars between Israel and many Arab countries of Jordan, Syria and Egypt, with regards to the establishment of Israel on Palestinian soil. As a result, the Palestinian conflict continued to be at the heart of the crisis and violence in the Gulf region till today. The successive Wars saw the expansion of Israel borders, and the escalation of the crisis in the region. The Palestinians and generality of the Gulf States have continued to call for the withdrawal of Israel from Palestinian conquered territories, while the Israelis at the same continued to enjoy military and diplomatic support of the United States. The conflict continuous to attract the attention of many States within and outside the Gulf region, and the United Nations has on many occasions intervened to create peace in the region, mostly in cooperation with the Gulf countries and Israel for peace to reign. The search for peace has remained elusive despite all effort and several peace negotiations pioneered at different times by different countries including Turkey.

For Turkey, its relations with Israel can only be understood from two main perspectives; it should first be seen from the perspective of Turkey's Westernization policy and its membership in NATO, and its alliance with the United States. Turkey-American relations and U.S-Israeli relations continued to define the relations between Turkey and Israel. Whereas Turkey's concerns towards Palestine can best be understood from the perspective of identity, and what Turkish diplomats have identified as traditional connections, which have to do mainly with religious and cultural perceptions, especially of Turkey's Ottoman past ${ }^{22}$ as an Islamic State to which all the Gulf countries paid allegiance before the creation of the State of Israel. This sometimes explains Turkey's relations with the Gulf countries and Israel.

Support for Israel as a result of its alliance with the West, and sympathy for Palestine is seen as arising from reasons related to identity. Turkey's relation with Israel has often been seen as a source of embarrassment in its relations with other Gulf States. It is sometimes seen as a betrayal of Turkey's Islamic heritage. Turkey was among the first countries that recognized Israel when it was founded in 1948, whereas all the Gulf countries at the time had refused to give recognition to Israel, since it's founding, it was not until after many years of diplomatic efforts that some of them accorded recognition to Israel. Turkey's policy towards Israel and Palestine appears somehow contradictory. Just as it recognized Israel, upon joining the OIC, Turkey recognized the rights of the Palestinians to their land and Statehood, and said it supported the cause of the Palestinian people ${ }^{23}$. Turkey for this reason is seen as pursuing a careful diplomacy and one of neutrality in the region especially in recent times due to the changing nature of its foreign policy. Turkey over the years became involved in many peace negotiations in the Arab/Israeli conflict, and sometimes its ability to balance its policy in

\footnotetext{
21 Ibid.p 509

22 Bulent Aras, "Turkey and the Palestinian Question", p 2

${ }^{23}$ Mahmut Bali Aykan, Turkey and the OIC:1982-1992, P 103
} 
accordance with the trend of the conflict determines its relations with other countries in the region.

There is no doubt that the Palestinian question occupies an important place in Turkey's policy towards the Gulf, since it is to an extent what has shaped the politics of the region and the existing alliances as well. Turkey's support for the Palestinians can be traced to as early as 1967 during the construction of Jewish housing units in East Jerusalem, as well as in 1969, when Jerusalem was announced as the capital of Israel, the Turkish government was critical about these developments. The Palestinian issue was seen to have received more boosts as a result of the zero problem policy of Turkey, coupled with the coming to power in Turkey of the AK Party, which is seen to be an Islamic Party. The new policy however seems to be one that is seen to deter Israeli aggression towards the Palestinians, as well as to condemn Palestinian attacks against the Israelis, and having good relations with both at the same time. Turkey had on many occasions offered to mediate in the conflict between the Israelis and the Palestinians, such as the Industry for Peace Initiative in Palestine. Through this, Turkey tried to create an industrial zone in the region, and saw trade as the basis of peace in the region. The TOBB, Chambers of Commodity Exchange of Turkey, showed its willingness and readiness to invest 100 Million USD in the project that if completed will see to the employment of 6,000 Palestinians ${ }^{24}$. There was support for the project from both the Israelis and the Palestinians which was to be cited in Gaza, that will made a free trade zone for both peoples. In the past Israel had always rejected Turkey's offer for mediation, but welcomed the TOBB project.

The coming of the AKP between 2002 and 2007 saw a drastic change in Turkey's foreign policy and outlook. The AKP was seen as having an Islamist outlook, and sought to maintain a cool approach towards Israel ${ }^{25}$ Turkey had sought to reconcile its differences in the region with countries such as Iran and Syria which are seen as staunch opponents of Israel. The AKP government continued to collaborate and cooperate with the Israelis and their Palestinian counterpart, even at the expense of criticisms from Turkish society, until the Operations Cast Lead in Gaza Strip when such relations fell or collapsed. The Gaza War saw a reversal in Turkey -Israeli relations, as the Turkish government criticized the operation which it called genocide. While the relations became sour, following the Gaza incident, the relations yet suffered another crisis which came too be known as the Mavi Marmara crisis in May 2010, where a TurkishIslamic NGO joined the Flotilla with many activists, as part of the free Gaza movement. While the ship was in the international waters on its way to Gaza after a blockade by Israel, Israeli Commandos stormed the ship and in the process killed 8 Turkish activists, and one TurkishAmerican, with many others injured from live bullets ${ }^{26}$. The UN condemned the actions of the Israelis, and Turkey on her part recalled her Ambassador to Tel-Aviv and gave conditions for resumption of relations. First was an apology, officially, second was to pay compensation for the families of those killed, and acceptance of a team of international investigators by Israel to investigate the incidence. Turkey further demanded the removal of the Gaza blockade. The Israelis were said to have complied with all the demands of Turkey but did not convey any official apology, and ever since then the relations remained bad, and further, in away affected Turkey's relations with the United States. It was only during the visit of the U.S. President Barrack Obama in 2013 that he brokered a peace and Israel tendered an apology to Turkey

\footnotetext{
${ }^{24}$ Bulent Aras, “Turkey and the Palestinian Question”,p 5

25 Ilker Ayturk, "The Coming of the Ice Age? Turkish-Israeli Relations Since 2002", Turkish Studies, Vol 12, No 4, December, 2011.p 676

26 Ibid.p 679
} 
which it had refused over the years. But even then, it will take some time before relations between Turkey and Israel would be normalized.

\section{Turkey in the Gulf}

Turkey's role in the Gulf is generally viewed in two different but interrelated perspectives. One is Turkey's overall relations with the Gulf/Middle East region in general, and two, is Turkey's relations with the Gulf States strictly ${ }^{27}$. Turkey is seen to be newly involved in both the affairs of the Middle East region as well as that of the Gulf States. Such perceptions are considered justifiable especially if the level of Turkey's involvement in the region and its distance as well as other historical factors is taken into consideration. For many years the Middle East region was not and did not occupy an important place in Turkey's foreign relations agenda and as a consequence, Turkey has not been considered as a major player in Gulf affairs and the Middle East region as a whole. Turkey's involvement in the affairs of the Gulf was generally viewed in a positive light by Gulf countries, and the perception of Iranian interference is seen to have strengthened the support enjoyed by Turkey from the Gulf States ${ }^{28}$. The Gulf States are seen to have been highly appreciative of Turkey's soft power approach which is seen to be promoting an atmosphere of peace and stability in the region. Despite the positive support enjoyed by Turkey so far from Gulf States since the involvement of Turkey in their affairs, many Gulf States have continued to question Turkey's interest in the Gulf. The Gulf States tend to look at the long term commitment of Turkey to its credible relations in the region ${ }^{29}$. The Gulf States continue to express their concerns on building a sustainable partnership based on mutual interest and trust with the republic of Turkey. The Gulf countries have shown interest in dealing with Middle Eastern affairs with Turkey, but do not welcome domestic involvement of Turkey in the affairs of the individual States. Turkey's involvement in the Iranian nuclear issue and the Lebanese politics tended to have raised the suspicion of the Gulf States about Turkey's intentions in the region ${ }^{30}$.

\section{Turkey-Gulf States Perceptions}

One of the factors identified as likely to hinder cooperation between Turkey and the Gulf States is the insufficiency of knowledge about one another by both the Gulf States and Turkey. There is clear misunderstanding of their respective priorities, agenda as well as their capabilities in the region and even beyond 31 . The Gulf States and Turkey are all seen to be only recently involved in regional affairs, and as such both parties are yet to actually understand their various objectives and positions on certain issues that affect the region. The lack of information on the policies, priorities and agenda of Turkey by the Gulf States recently resulted in the criticism of Turkey's policy towards Syria by the Gulf States. Such criticism was seen to have come about mainly due to lack of proper comprehension of Turkey's foreign policies by the Gulf States. The Gulf States generally seemed to have been disappointed in the manner in which Turkey is carrying out its support to the Syrian opposition in recent times ${ }^{32}$. In the opinion of the Gulf States, Turkey is not doing enough. The criticisms were countered on the grounds that the Gulf States may have been unaware of the international efforts the republic of Turkey has been involved in, with a view to enforcing a regime change in Syria. The Gulf States generally contend that the entire burden of supporting the Syrian opposition has been left to

\footnotetext{
${ }^{27}$ Saban Kardas, "Turkey and the Gulf Dialogue in the Middle East", Foreign Policy Programme, November 2012.p 5

28 Ibid.p 5

${ }^{29}$ Ibid.p 5

30 Ibid.p 5

31 Ibid.p 5

${ }^{32}$ Ibid.p 5
} 
them alone, whereas Turkish policy makers point to the efforts made by Turkey in not only forming the friends of Syria platform with the aim of gaining diplomatic international support for the Syrian opposition, but also sheltering the members of the opposition. The Syrian issue has clearly made known that the Gulf States do not fully understand Turkey's policy towards Syria ${ }^{33}$.

Another issue of concern between Turkey and the Gulf States is their perceptions regarding Iran and Turkey. While the Gulf States accept that the Iranian nuclear program was for peaceful purposes, they generally believe that Iran presents real and immediate threat to their security. Turkey on the other hand is aware of the threat that Iran poses, but Turkey does not view the Iranian threat as a major threat, or a threat to Turkey's interest in the Gulf. Opinions from the Gulf States are that Iran should be downsized for its interferences in the affairs of the Gulf States, and as a result suggest that counter balancing in the region should be a role that Turkey should assume ${ }^{34}$. Here also the divergence of policies between the Gulf States and Turkey is very clearly evident. Turkey has over the years been able to resolve its differences with Iran through years of conflict and cooperation, and would therefore not be willing to assume the role of counter balancing Iran as sought by the Gulf States. This divergence of perceptions by the Gulf States and Turkey may likely be a source of concern for the relations existing between the Gulf States and Turkey. Both sides are likely to continue to face some misunderstanding so long as they fail to recognize their capabilities and expectations of one another, and failure to do so may result in eroding the much needed trust to foster cooperation between both sides.

\section{Implication of Foreign Policy Choice in the Gulf}

There has been a lot of consideration for the likely future policy of the republic of Turkey in the Gulf region. There is absolutely no doubt also that the security of Turkey is connected to the international politics of the Gulf region. The Gulf region as a result presents to Turkey both threats and prospects ${ }^{35}$. The threats are viewed not only in military terms, but ideologically as well, as they threaten the legitimacy of the Turkish regime. There are threats of ethnic and religious diversity, and the availability of natural resources in the region, which may adversely affect the economy of Turkey, and is as consequence viewed with serious implications. But there are opportunities as well for Turkey, for trade and investment, energy supplies, cooperation and conflict resolution with regards to the Kurdish problem and the $\mathrm{PKK}^{36}$. Just as these threats and opportunities present themselves, The Turkish republic is on the other hand also presented with choices of foreign policy that will aid it to maximize benefits of these opportunities, while countering the threats at the same time.

Of the policy choices available for Turkey, is the Kemalist approach of neutrality, which may have the effect of a decline in relations with the United States and NATO, and may weaken support for Turkish army as well. It is however likely to increase trade between Turkey and Iraq, and increase energy supplies from Iraq. However it is seen as an uncertain policy and a difficult choice for Turkey, as a policy that will guarantee its security and economic interests simultaneously. Turkey could also assume a very active role in the region that will give it some predominance over the region, and align itself militarily with Israel. It is policy that may

\footnotetext{
33 Ibid.p 6

34 Ibid.p 6

35 Lenore Martin, “Turkey's National Security in the Middle East”, Turkish Studies, Vol 1, No 1, 2001, London.p 95

36 Ibid.p 95
} 
counter the Iran-Iraq military strength in the region, but will have the effect of strengthening Iran-Syria alliance, and may also spark off more coalition building between Arabs and the Iranians ${ }^{37}$. Not only that, it may as well lead to the subversion of Turkeys security by giving more challenge to the Turkish regime from radical Islamists and an escalation of the Kurdish problem. The policy may also likely affect the flow of energy resources into Turkey, with high implications for the Turkish economy. Maintaining a balance between neutrality of the Kemalist policy and the over active policy that strives to achieve regional predominance, is viewed as an alternative for Turkey. However, it is also seen as a policy that may be a little too complicated for Turkey to embark upon ${ }^{38}$. It requires the re-articulation of Turkey's national and foreign security policies, and Turkey will have to re-evaluate its bilateral relations with all major Gulf countries.

\section{CONCLUSION}

This article has clearly shown how the relations between Turkey and the Gulf States evolved in recent times, especially in the area of trade and commerce. Not only that, it has also shown the problems associated with these relations. It has shown the expectations and interests of both sides and what they hoped to benefit from each other. And from all these, one thing remains clear, and that is Turkey must consider a policy choice for such relations to endure, otherwise the relations may be faced with a lot of controversies and conflicts in the future, not only with the Gulf States, but also with other countries in the wider Middle East region, as well as with regional powers like Iran. Based on the expectations of the Gulf States, the Kemalist approach of neutrality may not be choice, just as the proactive role may be bring it into confrontation with other countries, here the best policy choice for Turkey, it would appear, is as discussed in the paper, striking a balance between neutrality and pro-activism, which may not be easy for Turkey too as well, as it is a little complicated, and may require the articulation of the country's national and foreign security policies, as well as the re-evaluation of the nation's bilateral relations with certain Middle Eastern countries like Iran, Iraq, Israel and some of the Gulf States like Saudi Arabia.

\section{References}

Ali .L Karaomanoglu, Turkey's Security in the Middle East

Andrew J.A Mango, Turkey and the Middle East

Bulent Aras, Turkey and the Palestinian Question

Bulent Aras, Turkey and the GCC States in the Twenty-First Century, September 3, 2010.

Dietrich Jang, Turkey and the Arab World: Historical Narratives and Political Realities, Mediterranean Politica, Vol 10, No 1, 2005.

F. Stephen Larrabee, Turkey Rediscovers the Middle East, Council on Foreign Affairs, August 2007.

Ilker Ayturk, The Coming of an Ice Age? Turkish-Israeli Relations Since 2002, Turkish Studies Vol 12, No 4, December 2011.

John Tirman, Inproving Turkey’s “Bad Neighborhood” Pressing Ankara for Rights and Democracy, World Policy Journal, 1998.

Kemal Kirisci, Post Cold War Turkish Security and the Middle East, Middle East Review of International Affairs, Vol 1, No 2, 1997.

Kenan Dagci, The EU's Middle East Policy and its Implications to the Region, Alternatives:Turkish Journal of International Relations, Vol 6, No 1\&2, 2007.

\footnotetext{
37 Ibid.p 96
}

38 Ibid.p 97 
Lenore Martin, Turkey's National Security in the Middle East, Turkish Studies, Vol 1, No1, 2000.

Meliha B. Altunisik and Lenore G. Martin, Making Sense of Turkish Foreign Policy in the Middle East Under AKP, Turkish Studies, Vol 12, No 4, December 2011.

Meliha Benli Altunisik, Worldviews and Turkish Foreign Policy in the Middle East, New Perspectives on Turkey, No 40, 2009.

Nuhu Yilaz and Kadir Ustun, The Erdogan Effect; Turkey, Egypt and the Future of the Middle East, Cairo Review, 2011.

Robert Olson, Turkey's Relations with the Gulf Corporation Council from 2003 to 2007: New Paradigms? Mediterranean Quarterly, 2008.

Saban Kardas, Turkey and the Gulf Dialogue in the Middle East, Foreign Policy Programme, 2012.

Saban Kardas, Turkey: Redrawing the Middle East Map or Building Sandcastles?, Middle East Policy Council, 2010.

Sabin Sayari, Turkey and the Middle East in the 1990's, Journal of Palestine Studies XXXVI, No 3, 1997.

Sean Foley, Turkey and the Gulf States in the Twenty-First Century, September 3, 2010. 